\title{
An Assessment of Factors Affecting Private Saving: A Case Study on Anasora Woreda, Oromia Regional State, Ethiopia
}

\author{
Bogale Boshe \\ Africa Beza College, department of Accounting and Finance, Hawassa, Ethiopia
}

\begin{abstract}
In developing countries like, Ethiopia, where there is low foreign direct investment and low capital inflow from remittance and export, local saving has a significant effect on investment and national economic development as a source of finance. Though this is the case the saving from some parts of the country, Ethiopia is beyond the expectation from them. Hence this study is made by the target an assessment of factors affecting private saving on Anasora woreda, using stratified sampling of 268 samples from salaried employees, traders and farmers. The researcher used exploratory type of research conducting as it needs, with the descriptive statistics to analysis the data. With this research result, low income and poor saving culture of the society, seasonality of business, large family size, saving awareness and inaccessibility to financial institutions have greatly impacted the private saving of the woreda. Based on the study findings we recommend that all the economic stakeholders which include the concerned woreda administrators at each level, the financial institutions and the society at large have the responsibility to change the current saving situation of the woreda people.
\end{abstract}

Keywords: saving, private saving, investment, private investment, economic growth and development

DOI: $10.7176 / \mathrm{DCS} / 11-1-03$

Publication date: January $31^{\text {st }} 2021$

\section{Introduction}

\subsection{Background of the study}

The importance of saving can be seen both at micro and macro level. For a house hold, it helps in maintaining the precautionary balances against shocks, keep smooth consumption in the face of volatile income, and support investment and physical capital, build up cash collateral, and serve as a truck record to allow them easier access to credit. At macro level, high saving rate could increase the amount of creditable capital which will push up the investment, and then the economic development and economic growth rate (CBE, 2015). In an open economy with access to foreign capital, funds will flow to investment projects with the highest expected rates of returns and domestic saving doesn't constrain investment and growth. But, with the inefficiency of the world economy and different constraints to foreign capital, foreign capital could not be reliable source of finance. Hence, it is clear that the economic development of a country depends largely on its ability to mobilize the necessary savings to finance capital formation in order to raise the nation's productive capacity. Low saving rate remains typical characteristics of developing countries, and the sub-saharan countries are the lowest of developing countries. The Ethiopian case is worse than the sub-Saharan and between 2005 and 2011; the average gross domestic saving was $6.42 \%$ of GDP (CBE, 2012).

Low domestic savings coupled with unpredictability of aid have compounded the challenge of financing the development of the country, Ethiopia (MOFED, 2013) justifying that to sustain the rapid economic growth of the country increasing domestic saving rate is unquestionable.

Low saving rate of the country as determined above is the summation of low saving rate of the different regions, zones, districts and localities, even though their contribution to the total saving is different and can be relatively ranked from low to high. Hence, in this research I try to investigate the extent of saving, and potentials available with its challenges to save and then suggest mitigation mechanisms based on the research findings in Anasora woreda, in where there is a high suspect of low saving but no supporting documents yet studied.

\subsection{Statement of the problem}

According to Rogg (2006) serious problem confronting poor countries including Ethiopia is the savings and investment gap. Because of this gap, these countries find it difficult to finance investments needed for growth from domestic saving. It is also common to see these countries to finance their investment in the short run partly through domestic government borrowings and/or foreign loan and grants but this would significantly increase the country's debt burden and would not be a solution in the long run.

However, both economic variables are not emphasized as a major variable for interventions for overall development in Africa in general and Ethiopia in Particular. This is the case mainly because of, first, most of the studies carried out in the field have focused on developed economies and unable to show the ground reality in poor developing countries. Second, most of these studies adopted a macroeconomic approach yet the behavior of economic units on the aggregate level may not necessarily be the same as on an individual or household level. And third, even the existing limited empirical research results in Africa related to rural household savings and 
investment are varied and inconclusive (Zhu, 2004).

The saving level in Ethiopia particularly in rural areas is very low and little is known empirically about its patterns and determinants. Savings in rural Ethiopia is mainly made out of the income from agricultural activities. It is also characterized as seasonal and irregular as the cash flow through sale of agricultural produce and availability of work is seasonal. This reduces their financial capacity to save or poorly respond to incentives that promote savings in the country (Aron, 2013; EEA, 2009). However, rural households do indeed save in the form of tangible assets and/or in financial forms which can be potentially utilized by savings institutions and for investments which is very essential for both households and national wellbeing (Girma,T.,2013; Karlan and Morduch, 2010). Therefore, this study tries to analyze major determinants of savings behavior of rural households which has been less addressed in Ethiopia.

There was marketing research done by the commercial bank of Ethiopia, Erba Muda branch in September 2015 on the assessment of the saving potentials of the area using solely secondary data sources from the woreda office. The study result shows that there are significant potential for the peoples to save for their investment and future life. However, though the only bank in the area cited above has encouraged the society to save at the bank there is no significant improvements in their saving habit. Beside this the area is known with variety of mineral resources aside from the agricultural productivity (cattle rearing \& crop production). Hence, in this research, the researcher is encouraged to find the gap between the research conducted by the bank and the actual savings seen at the bank branch. Hence, the objective of this thesis research is to assess the factors that are currently affecting the saving conditions of the Anasora woreda households \& businesses.

\section{Research Design and Methodology \\ 2.1 Description of the study area}

The area where the research is conducted is Anasora woreda, Guji zone. It has a distance of $410 \mathrm{~km}$ from Finfinne/Addis Ababa and 180km from Negelle (capital city of Guji zone). It has an area of 47,523hek or 475.23 $\mathrm{km}^{2}$. It is an area where mixed farming economic activities were the livelihood of the people. The life of the society is largely depends on producing crops like maize, bean, barley and the like. They also breed animals like cattle, horse, goat \& sheep as their main occupation. The area is also known with animal products like butter and honey. Part of the society living there are farmers, government employees, workers under private employer, self-employed, small \& medium scale traders. Most of the productions like crops \& honey are seasonal, usually from February to June. The rest time of the year is rainy season in which businesses culminate. Almost there are no large commercial activities and big manufacturing industries in the area except one kaolin factory which produces raw material for ceramic production. The elevation of the woreda ranges from 1450-2900meters, has annual rainfall nearly about $122.7 \mathrm{~mm}$ and the annual temperature of the area ranges from 10.1-20c (Guji zone FEDO). Regarding trade there is no known local cash crops in the woreda.

\subsection{Research design}

The researcher used both exploratory and descriptive types of research designs (Qualitative) in which the researcher wants to explore the reason behind the problem on private saving \& investment on the woreda area, and describe using simple statistical tools like percentage analysis, graphs \& charts, interpret the results/findings and reached to general conclusions.

\subsection{Population \& sampling technique}

The total population of the woreda house holds is estimated to be 24,278 as to the 2007E.C data from the woreda health office. The sampling techniques employed was stratified random sampling by basing their occupation and then use simple random sampling technique so as to get fair(average) data, and to make the sample fair and representative of the population, the sample size was determined using a formula based on the Raostat sample size calculator. At $90 \%$ confidence level, margin of error (e) $5 \%$, and with $50 \%$ response distribution using the above Raostat sample size calculator $n=268$, where $n$ is required sample size

\subsection{Data Collection Methods}

The main data source used in the research was primary data collected from respondents using questionnaire in person directly approaching the individual households or respondents from which the researcher hoped to get information that is reliable \& valid and help to identify the problem, and purposive semi-structured interview for issues that require clarification to concerned individuals like the woreda administrator, woreda finance\& economic development head, selected farmer households and community leaders (like Aba Geda) who understand the socioeconomic condition of the society in which they live and the study purpose, and then justify more than others. To some extent secondary data like demographic, socio-economic, geographic and climatic data are used from the concerned woreda office like labor and social security office for the employment and income status of households, agricultural office for the width and productivity of crops \& animals in the area as the place is rural town, trade 
office for the rate of trade at the chosen research area, commercial bank of Ethiopia(Erba muda branch) and Oromia credit \&saving share company(Anasora Branch) to get data concerning private saving at the available financial institutions in the area.

\subsection{Methods of Data Analysis}

After sorting and checking data collected using questionnaire and interviews from respondents for its correctness and completeness, was prepared in the form of tables. The data analysis methods used were descriptive statistics as the case of qualitative analysis of the respondents data using percentage and other related methods, and presented in different charts and graphs as necessary for evaluation and comparison purpose, and then interpreted the findings.

\section{Data Analysis and Interpretation}

According to Raostat sample size calculator, the sample size, $n=268$, at $90 \%$ confidence level, margin of error (e) $=5 \%$, and with $50 \%$ response distribution was used by the researcher. And the response rate was 230 out of the 268 questionnaire distributed, and hence the response rate was $85.82 \%$. From the questions provided to the respondents which include both demographic information and questions related to the research topic the following data were obtained:

Table 3.1: Sex ratio of respondents

\begin{tabular}{|l|l|l|}
\hline Sex & Number of respondent & percentage \\
\hline Male & 192 & 83.48 \\
\hline Female & 38 & 16.52 \\
\hline Total & $\mathbf{2 3 0}$ & $\mathbf{1 0 0}$ \\
\hline
\end{tabular}

Source: researcher field survey, 2016

From the above table 1 the researcher observed that the high part of the woreda people educated, able to read, understand and respond the questionnaire is male. As Wolday \& Tekie cited on CBE, 2015 discussed male headed households are expected to save more than the female households, as they have higher income than the female households. On the other hand, it is argued that female headed households have the tendency to consume less. They also discussed that there are no general agreement on empirical results that has been done.

Table 3.2: Age category of the respondents

\begin{tabular}{|l|l|l|}
\hline Age (in years) & Number of respondent & percentage \\
\hline $15-20$ & 14 & 6 \\
\hline $21-40$ & 148 & 64.35 \\
\hline $41-60$ & 65 & 28.26 \\
\hline$>60$ & 3 & 1.39 \\
\hline Total & 230 & 100 \\
\hline
\end{tabular}

Source: field survey, 2016

The above table 2 clearly indicates that the majority of the respondents are between 21-40 years of age and it is the high productive life cycle for an individual in any occupation. According to the Life Cycle Hypothesis by Franco Modigliani and Richard Blumberg age of households affect saving behaviors. It says as household's age increases, their savings will decrease. On the basis of the Life Cycle Hypothesis, Agrawal (2001) also noted that individuals will have negative savings when young and have low or no income, positive savings during their productive years and again negative savings when they are old and retired. Hence, the major respondents' age is the age with in life cycle to work hard and able to save for his future investment and personally grow.

Table 3.3: Education Qualification

\begin{tabular}{|l|l|l|}
\hline Level & Number & percentage \\
\hline Illiterate & 14 & 6 \\
\hline Able to read \& write & 16 & 7 \\
\hline $1-4$ & 5 & 2.2 \\
\hline $5-10$ & 56 & 24.3 \\
\hline Diploma & 55 & 24 \\
\hline First degree & 79 & 34.3 \\
\hline Second degree and above & 5 & 2.2 \\
\hline Total & 230 & 100 \\
\hline
\end{tabular}

\section{Source: field survey}

The table above indicates that about $60.5 \%$ of the respondents have at least diploma in their education. But, this percentage may not represent the education level of the total population and it is from those who could able to respond the questionnaire. As wolday \&Tekie cited on CBE, 2015 as households' level of education increases, they will be better aware of financial institution and financial products, which in turn improve their saving behavior 
and use of formal sectors. In this regard the major respondent can easily understand the benefits of savin, different forms of saving, and how to enhance saving.

Table 3.4: Occupation of Respondents

\begin{tabular}{|l|l|l|}
\hline Occupation & Number of respondent & percentage \\
\hline Government employee & 47 & 20.4 \\
\hline Private org. employee & 11 & 4.8 \\
\hline Farmer & 98 & 42.6 \\
\hline Trader & 60 & 26.1 \\
\hline Other & 14 & 6.1 \\
\hline Total & 230 & 100 \\
\hline
\end{tabular}

Source: Field survey of the researcher, 2016

The table above clearly explains the majority of the respondents base their life on agriculture (farming), small scale trade, and government employees respectively. Occupations of the respondents categorized under other category are those respondents who are engaged in church leading, carpenter $\&$ clinic owners. Wolday \& Tekie cited on CBE, 2015 clearly indicated that Main livelihood activities or work status of peoples or households determine individual saving behaviors. As to them Households may have different saving motives based on their engagement in economic activities. The self-employed households, for instance, are expected to save more, because of the uncertain nature of their income. Conversely, salaried employees being certain on the flow of their income, they are expected to save less

Table 3.5: Response related to the estimated annual revenue of respondents

\begin{tabular}{|l|l|l|}
\hline Estimated Annual revenue of respondents(in birr) & Number of Respondent & Percentage \\
\hline $0-10,000$ & 63 & 27.4 \\
\hline $11,000-30,000$ & 71 & 31.0 \\
\hline $31,000-70,000$ & 74 & 32.1 \\
\hline$>100,000-100,000$ & 16 & 7.1 \\
\hline Total & 6 & 2.4 \\
\hline
\end{tabular}

Source: Field survey, 2016

As from respondents, $90.5 \%$ of the respondents gain estimated annual revenue less than 70,000birr. This may indicate income is their main challenge to save after settling their consumption expenditure. Wolday \& Tekie cited on CBE, 2015 noted that Income households' disposable income is probably the most important variable determining the level of saving. As income rise, the proportion of household asset in a financial form is expected to rise that enable them to have surplus fund to save. But it depends on more of the other variables like dependency ratio and personal life style. People with the same income will not save equal as their consumption pattern and expenditure varies. The above literature also indicates other things being the same, the higher the proportion of household members that consume more than they produce, the lower will be the household saving.. Thus, the distribution of population will affect the savings rate. However, it is argued that among rural families, even children can contribute significantly to the household's production and income. Other researchers empirical result like Dejene(2003) indicate at household level, irrespective of small size, rural household in Ethiopia do save in many ways, as individuals or in a group. They usually save in kind mainly in food-grains or in livestock. This in turn shows individuals who adapted a good saving culture do save a certain percentage of their income whatever their income will be.

Table 3. 6: Saving Awareness level of Respondents

\begin{tabular}{|l|l|l|}
\hline Saving awareness level & Number of respondent & Percentage \\
\hline Excellent & 17 & 7.2 \\
\hline Very good & 31 & 13.5 \\
\hline Good & 74 & 32.2 \\
\hline Low & 108 & 47.0 \\
\hline Total & 230 & 100 \\
\hline
\end{tabular}

Source: field survey of the researcher, 2016

As from the table 6 above, it shows that the majority of the respondents have got less awareness on the benefits of saving. 
Table 3.7: Annual saving of Respondents

\begin{tabular}{|l|l|l|}
\hline Average Annual saving(in birr) & Number of respondent & percentage \\
\hline $0-5,000$ & 49 & 21.4 \\
\hline $5,000-15,000$ & 74 & 32.1 \\
\hline $15,000-50,000$ & 33 & 14.3 \\
\hline $50,000-100,000$ & 11 & 4.8 \\
\hline$>100,000$ & 5 & 2.4 \\
\hline No Response & 58 & 25 \\
\hline Total & 230 & 100 \\
\hline
\end{tabular}

Source: Researcher field survey, 2016

The table shows that more than half $(53.5 \%)$ of the respondents have average annual saving of birr less than 15,000 birr. This confirms the research done by Girma et al.2013 stated as in its findings saving level in Ethiopia particularly in rural areas is very low. According to MOFED (2012), the average gross saving rate as percentage of GDP of Ethiopia is $21 \%$

It was also supported by Dejene, 2003 that low saving has been a dominant feature of the Ethiopian economy. According to his research the average share of gross domestic savings and investment from GDP was 12.4 and 18.5 percent which is very low even to the standard of developing countries, respectively.

Table 3.8: Forms of saving being used by the respondents

\begin{tabular}{|l|l|l|}
\hline Forms of saving used & Number of respondent & percentage \\
\hline Bank saving & 60 & 26.3 \\
\hline Ocssco & 36 & 15.8 \\
\hline Livestock & 34 & 14.7 \\
\hline House building \& furniture & 10 & 4.2 \\
\hline Commodity purchase for future sale \& consumption & 15 & 6.3 \\
\hline Money kept at home 'kazina' & 29 & 12.6 \\
\hline Ekub & 29 & 12.6 \\
\hline Credit \& saving institution & 5 & 2.2 \\
\hline Other & 12 & 5.3 \\
\hline Total & 230 & 100 \\
\hline
\end{tabular}

Source: researcher field survey, 2016

As from the table shown above about $26.3 \%$ of the respondents use bank saving and most of them are salaried government employees. About $15.8 \%$ of the respondents save at the Oromiya saving \& credit share company (Ocssco), which almost all are borrowers of the institution to finance their business and the institution encourages them borrowing through depositing or saving initial which is tied with the government chain of organizing unemployment or the poor people especially women \& young through the woreda micro \& small enterprises agency cooperation. $14.7 \%$ of the respondents save through buying livestock when they are cheap and sell when they are expensive or breed them to get higher profit. There are also many peoples who purchase commodities (like cereals) and other precious materials like gold \& tantalum to use for the same purpose. Money kept at home like in 'kazina' and under mattress as well as used as 'Ekub' are almost equal and each are 12.6\% of the total respondent. People of the area use keeping money at home and in 'Ekub' form are to use immediately when required urgently (this may be linked with bank inaccessibility and Ocssco liquidity problems) and to get huge amount of money at a time without interest to run their business, respectively. Other types of savers are those who use the different saving combination of the above forms (like bank deposit, buy and keep different products and Ekub).

Table 3. 9: Respondents reason for choice of financial institution

\begin{tabular}{|l|l|l|}
\hline Reason for choice of financial institution & Number of respondent & percentage \\
\hline Easy to use the service & 38 & 16.5 \\
\hline Accessibility & 19 & 8.2 \\
\hline Helps me to grow my business & 76 & 32.9 \\
\hline Loan facility & 11 & 4.7 \\
\hline Liquidity (easiness to withdraw) & 65 & 28.2 \\
\hline Gain huge money at once without interest & 21 & 9.3 \\
\hline Total & 230 & 100 \\
\hline
\end{tabular}

Source: researcher field survey, 2016

As shown above the large percentage of respondents choice of their financial is based on either in that it will help their business to grow $(32.9 \%)$ or the ease in liquidity (to easily use when urgently needed for a purpose) $(28.2 \%)$. This are they are concerned with the loan facility and the accessibility of the financial institution respectively. The other more weighted that make 
The decision to choose financial institution is the ease to transact with or the service delivery available like speed and technology usage of the financial institution (16.5\%). Rural people save at their home in different places in kazina or under mattress because of their far distance from formal financial institution to use their money when urgently needed for their business.

Table 3.10: Respondents saving habit

\begin{tabular}{|l|l|l|}
\hline Saving behavior of respondent & Number of respondent & percentage \\
\hline High & 51 & 22 \\
\hline Medium & 92 & 40 \\
\hline Low & 87 & 38 \\
\hline Total & 230 & 100 \\
\hline
\end{tabular}

Source: researcher field survey, 2016

From the table 10 above, the large percentage of the respondents gave their response on their saving behavior from medium to low (40\% and 38\% respectively). And those who confirmed that their low saving habit has justified by the next question provided to them blaming low income, lack of nearby financial institution, and their poor expenditure management among other factors.

Table 3.11: Extent of saving compared to their income

\begin{tabular}{|l|l|l|}
\hline Is your saving in any form is enough as compared to your income? & Number & Percentage \\
\hline Yes & 103 & 44.7 \\
\hline No & 127 & 55.3 \\
\hline Total & 230 & 100 \\
\hline
\end{tabular}

Source: researcher field survey,2016

It shows that more than half $(55.3 \%)$ of the respondents believed that they have poor saving culture when compared to their income they gain, and the reason they gave for their poor saving was awareness, high expense as compared to income, large family size, low bank saving interest rate, daily business run for the sake of higher profit rather than saving in any form is their main reason for not saving as expected from their income.

\section{Table 3. 12: Frequency of bank usage}

\begin{tabular}{|l|l|l|}
\hline Are you making your financial transaction regularly through bank? & Number of respondent & percentage \\
\hline Yes & 148 & 64.3 \\
\hline No & 82 & 35.7 \\
\hline Total & 230 & 100 \\
\hline
\end{tabular}

Source: researcher field survey, 2016

Those who have frequent contact with the bank are traders, government employees, and few rural households like farmers who have got awareness about the bank products \& bank service.

Table 3.13: Respondents challenge to use bank regularly as they need

\begin{tabular}{|l|l|l|}
\hline What is your main reason for not using bank regularly? & Number of respondent & percentage \\
\hline Awareness & 14 & 17.2 \\
\hline Distance from bank & 20 & 24.1 \\
\hline Use Ocssco & 6 & 6.9 \\
\hline Fear to use bank & 5 & 6.0 \\
\hline Poor bank service & 14 & 17.2 \\
\hline Ekub & 20 & 24.1 \\
\hline Local credit \& saving & 3 & 3.4 \\
\hline Total & 82 & 100 \\
\hline
\end{tabular}

Source: researcher field survey,2016

Large number of respondents blamed distance from bank (accessibility) and choice of the local rotated credit among groups (Ekub) for not frequently use bank which are followed by awareness problem and poor bank service. As from the table above, there are also peoples who fear bank using because of their perception of losing their money by not having confidence on bank thinking it passes information to tax authority or court when needed. But, this is not true and they misunderstood the bank business activity and the other government organization authority with their responsibility. On the other hand their genuine property is their own can't be of other and cannot be taken by government or any other body established legally. 
Table 3.14: Challenges to improve saving practice

\begin{tabular}{|l|l|l|}
\hline What is your real challenge to improve your saving practice? & Number of respondent & percentage \\
\hline Income & 77 & 33.3 \\
\hline Awareness & 42 & 18.4 \\
\hline Large family size & 29 & 12.6 \\
\hline Seasonality of Business/work & 37 & 16.1 \\
\hline Lack of credit facility & 8 & 3.4 \\
\hline Absence of bank online service & 32 & 13.8 \\
\hline Other (inflation) & 5 & 2.3 \\
\hline Total & 230 & 100 \\
\hline
\end{tabular}

Source: Researcher field survey,2016

The large part of the respondents blamed income, saving tools and benefit awareness gap, and seasonality of business/work which is followed by poor bank service and large family size of the people for not to improve their saving practice. The other factor that challenged them is inflation, which made prices of food and other commodity prices to increase and negatively impacted their saving.

Table 3.15: Respondents' opinion on the reason for the low investment condition of the woreda region

\begin{tabular}{|l|l|l|}
\hline $\begin{array}{l}\text { What do you think the reason for the low investment condition of the } \\
\text { woreda area? }\end{array}$ & $\begin{array}{l}\text { Number } \\
\text { respondent }\end{array}$ & percentage \\
\hline Low income of individuals & 98 & 42.7 \\
\hline Low saving culture of individuals & 26 & 11.4 \\
\hline Fear of investment risk & 14 & 6.2 \\
\hline Lack of investment opportunities & 29 & 12.5 \\
\hline Lack of investment opportunities & 60 & 26.0 \\
\hline Other & 3 & 1.3 \\
\hline Total & 230 & 100 \\
\hline
\end{tabular}

Source: researcher field survey, 2016

According to the response from respondents, what largely affected the private investment condition on the woreda area is low income of individuals, and according to them those who has income has lost investment information on the investment opportunities available to the on the woreda area to invest and which is hoped to increase the saving and economic progress of the area. Though their numbers are comparatively small, there are also respondents who suggested as there is no investment opportunity on the woreda area, and also who have fear on investment risk like security of their business in connection with political instability. The other factors which affected their investment are low or lack of investment loan facility to individuals.

Table 3.16: Relationship of private saving and private investment

\begin{tabular}{|l|l|l|}
\hline $\begin{array}{l}\text { Do you think that private saving and private investment } \\
\text { have direct relationship? }\end{array}$ & Number of respondent & percentage \\
\hline Yes & 181 & 78.6 \\
\hline No & 49 & 21.4 \\
\hline Total & 230 & 100 \\
\hline
\end{tabular}

Source: researcher field survey,2016

From the result it is indicated that the large portion of the respondents knew that private investment results from individual saving to accumulate wealth. As to them no investment is possible without prior hardworking on any interested work or business to oneself and save money. Others who are low percentage respondents believe that one made investment only if there is credit facility, donation or high source of income, and they think that as private saving and private investment has no any relationship. But, according to (Schmidt-Hebbel et al; 1996; Bisat et al, 1997; and Sinha, 1999) long-term economic growth requires capital-investment in infrastructure, education and technology, business expansion, and so forth, and the main source of funds for capital investment is household savings.

\section{Analysis of Open questions presented to respondents}

In this open question types the researcher wanted full feelings and their understanding level of respondents on what has to be done and by whom to improve the current saving and investment condition of the woreda area.

Analysis for the questions asked saying 'what do you think the society must practice to improve the current saving and investment condition of the woreda?'

For this question presented to respondents, most of them has responded as the society need to improve its consumption and expenditure pattern; make saving as the basis of their future good life; practice investment as they can by watching the investment opportunities available to them rather than only waiting the government to come and invest. For this they recognized that the need of improving and saving culture by the general society of 
the woreda dwellers as to them is vital to enhance the economic progress of the woreda and then contribute to the economic growth of the nation as a whole.

Analysis for the question asked as 'what do you think the concerned government body at each level must perform in order to improve the current private saving and investment in the woreda?'

The respondents respond as the local government body like the woreda and kebele administrators, and their different sector heads represent the society of the woreda, and hence, each concerned government bodies at each level must always consider the shortfalls of the society they lead; create smooth working atmosphere, for the people to work and get income; provide investment opportunities and information; do public investment which is the basis for private investment improvement; create awareness and motivate people to save and invest; bring and connect different saving and lending financial institutions, and investors to the area.

Analysis for the questions asked as 'what shall be done by the financial institutions for the private saving and investment on the woreda to grow up?'

For the private saving and investment on the woreda to grow, the respondents replied as microfinance institutions like banks and ocssco have to increase their accessibility to every corner of the woreda region, create awareness aggressively on saving and investment benefits as well as the products and services available by them, encourage them through different mechanisms; provide loans to help them in their business; increase their service by using up-to-date technologies to speed up customer service and minimize transaction cost; improve loan/credit process and saving deposit interest rate.

Hence, from the above three questions presented to respondents and their analysis it was determined that it is the responsibility of the concerned government body, the financial institutions working on the woreda, and the general society to improve the current saving and investment condition on the woreda.

\section{Analysis of the semi-structured interview conducted with the Anasora woreda administrator}

In this semi-structured interview the researcher wanted to understand and diagnose the actual and potential of the woreda area on saving and investment, and at the same time to stimulate them on the issue by each of their concerned sub-sectors to enhance saving and investment by the sequentially presented questions to him by the researcher personally and directly accordingly.

Analysis on the questions asked as 'What are the main revenue sources of the woreda?' For this question presented from the researcher to the administrator of the woreda, he replied as the main revenue sources of the woreda are primarily from the sale of agricultural products of crop production and cattle breading. The main crop products produced with in the woreda area in order are maize, wheat, barly, bean and the others in small scales. The cattle breading practiced there by the farmers individually are livestock as cows, goat and sheep. As the area is of high altitude and rainfall, and the area is characterized as 'Dega' region horses breading are common and they are usually used for transportation and sale for income generation. According to the administrator, there are no such locally known cash crops as coffee and 'chatt'. But, there is hope and a start to produce the above mentioned products in the area as the climate changing in to warmer condition ('woina dega') as the general global climatic change trend. There are also small scale trade and hotel business activities within the woreda towns but there is a need to be improved with these sectors to ensure the welfare of the society.

Analysis for the questions asked as 'what are the investment opportunities available within the woreda region?' The woreda is known for so many investment opportunities but not utilized and changed the walfare of its people. As from the administrator, the main investment opportunities in the area are the fertile land that can be used for production of different crops like coffee, chatt and other cash crops as mentioned above. The second investment opportunity in the localities are the large part of the woreda area can be used for irrigation and produce different agricultural products for consumption and sale to generate revenue, also which may be exported and bring foreign currency for the country. The other and the most investment opportunity here is the availability of valuable and precious minerals like gold, tantalum, and others which are not yet changed in to investment but have the potential to change the current economic condition of the area.

Analysis for the question asked as 'how do you explain the benefit of private saving to an individual, a family and country?'

Saving is mandatory to a person to teach and support his/her children with their basic needs; to live better life tomorrow or during his/her retirement age, and ensure the welfare of his family in general. And by doing so, he/she contributes to the national economic growth in one or the other way. According to the word from the administrator, if one has to work hard and get a certain amount of money from his/her income generated, then beyond supporting his/her family the person may invest on something he/she can and interested to do with the help of government policies to create employment opportunities for his dependent other citizens. Above this, what is then produced from the business operation may be very useful to the society or a country in either form that may be exported and generate hard currency for the nation to support different development projects within the country. It also may create many business opportunities for the others through backward and forward integrations.

Analysis on the question presented 'How much of the woreda population are aware of the benefits of saving 
and how much of them are practicing saving as their life principle?'

The administrator recognized that financial institutions like the commercial bank of Ethiopia and the oromiya saving and credit share company working on the woreda region continuously give awareness to the society at different places like on public meetings, market places, school, door to door at their home and other places to teach and motivate the people to save at their own nearby branches of the respective institutions. And according to him the local government must support the efforts of the financial institutions (CBE and OCSSCO) has not been done to the expected level, and he added that the woreda government doesn't have the exact figure for how much got awareness and also how much is practicing saving and simply estimated that about $25 \%$ of the people do save from the income they get from any source, but this figure is too far from the general sub-Saharan countries presented by other researchers and MOFED (2012) report which it says the saving culture in rural Ethiopia was less than $6.42 \%$.

Regarding the impact of both saving and investment, he responded as if both private savings and private investment amount are very low and that it greatly affected the economic growth of the woreda for which it left behind in many of the growth measures. Hence, he pointed out that people must work hard, save their income and invest in their localities rather than simply waiting the government or others to come and invest.

Analysis to the question asked as 'what means do you suggest for the savings to grow in the woreda?'

For the above questions presented to the administrator, he replied saying that for the in the woreda to grow the saving culture of the society must be changed, for to do so there are tasks to be done in the short run as well as in the long run period by different stake holder as a strategy tool. One thing is that, in the short run, as they already started it financial institution must strengthen their awareness creation to the society from corner to corner. They also have to provide credit facilities in order to motivate their effort and help their business; increase their accessibility and quality of their service in general. Undeniably equivalent, in the long run, the concept of saving and investment must be given to children at school. There must also tasks to be done by the government to decrease the dependency ratio by creating job opportunities for the young through small and micro-enterprises; teach family planning and how to minimize their expenditure to the society at large.

What do you think things to be done by the concerned local government bodies at each level to do in order to enhance the saving condition of the society?

The concerned local government which includes the woreda administrator and its sub-sector like the woreda finance and economic development, and investment offices must be committed and create awareness to the people, beside this they must identify and help in their challenge in this regard. In other words kebele administrators have the responsibility and potential to support government strategies planned to improve the welfare of the society.

\section{Conclusion and recommendation \\ 4.1 Conclusion}

From the research conducted using sample respondents and semi-structured interview conducted with the Anasora woreda administrator, and its analysis made with the help of the theoretical and empirical literature review, the following conclusions can be drawn:

- The actual saving potential of the Anasora woreda is low in contrast to the woreda sectors offices report data because of the low income sources of the people.

- Though their income is low, the saving culture of the woreda society is very poor

- The challenges of the households and businesses of the study area to make saving are income, seasonality of business, high dependency ratio, awareness and inaccessibility of the financial institutions

- The saving deposits of the commercial bank of Ethiopia, Erba muda branch, become low because of the low income level and poor saving culture of the society, bank inaccessibility to most of the remote areas from the bank branch, low awareness created, and low investments made in the area. Beside these all, the poor bank service had also contribution to the branch ineffectiveness. Above more, the area is not known with local cash crops and high commercial works.

- As they have casual relationships from the theoretical and empirical literature, the factors mentioned above have negatively affected saving from the woreda revenue generated; low saving in turn affected investment, and investment also slow dawn the economic growth of the woreda

- Salaried and slightly higher income earner people choose bank saving, where as the small scale traders choose either micro-finance or 'Ekub' to finance their business. On the other hand those who have bank inaccessibility problems make their income to purchase livestock or put it in a 'Kazina' to get higher profit and keep safety of cash liquidity problems during emergency case, respectively.

- The poor private saving condition of the woreda society has a negative impact on the woreda investment and economic progress, and then on the national economic development.

\subsection{Recommendations}

1. It is the responsibility of the concerned woreda administrators at each level, the financial institutions and the 
society at large to change the current saving situation of the woreda people. Beside these, other institutions like church leaders, community leaders ('Aba Gadas'), NGOs and others can have their own impact on the overall solving of the general socio-economic problems identified by the research and ensure the welfare of the society, and then they will able to contribute their share in national economic development.

2. Financial institutions like the commercial bank of Ethiopia and the Oromiya credit \& saving institution have to increase their accessibility so as peoples at the every corner of the woreda can easily access them with little time and low transportation cost. In addition to these they have to improve their service quality like able to deliver fast service with low transaction cost by using up-to-date financial and information technologies. They must also provide the society oriented products like credit facility and saving schemes.

3. Public (government) investments like road, electric power, telecommunication, big factories based on the local resource (minerals) targeted social benefit in its business package and other establishments may encourage savings, private investment and economic progress of the area. This is because it minimizes unemployment, enhance income status of individuals, and it also creates many investment opportunities for the others as a result of public investment. Specially, the telecommunication infrastructure (broad band) directly related with the financial institution and the society saving service.

\section{REFERENCE}

Aron, H. Nigus, A. and Getnet, B. (2013). “Assessment of saving culture among households Ethiopia”,Journal of Economics and Sustainable, 4(15).

Ethiopian Economic Association (2009): Statistical Data Base, CD ROM. Addis Ababa, Ethiopia.

Girma,T., Belay, K., Bezabih, E. and Jema, H. (2013). "Determinants of rural household savings in Ethiopia: The case of East Hararghe zone, Oromia regional state". Journal of Economics and Sustainable Development, 4 (3).

Karlan and Morduch, (2010). Handbook of Development Economics, Volume 5

Ministry of Finance and Economic Development (MoFED) .(2013). "Development growth and transformation plan annual progress report for F.Y. 2012/13",Addis Ababa, Ethiopia.

National Bank of Ethiopia(2012), "NBE's Monetary Policy Framework", Economic Research and Monetary Policy Process, NBE, Addis Ababa, Ethiopia

NBE (National Bank of Ethiopia) (2014/15). Annual Report . Addis Ababa:

Rogg, C., (2006). Asset Portfolios in Africa Evidence from Rural Ethiopia. UNU-WIDER, Centre for the Study of African Economies, University of Oxford. Department for International Development (UK). Research Paper No. 2006/145.

Zhu, Q., (2004). The Impact of Rural Enterprises on Household Savings in China. ZEF -Discussion Papers on Development Policy Bonn, Germany. 